\title{
The Rise of the Hindu Religious Factor in Indian Politics and State Theory
}

\author{
Côme Carpentier de GOURDON \\ Convener of the International Board of WORLD AFFAIRS - The Journal of International \\ Issues (India). Address: D-322, Defence Colony, New Delhi, 110 024, India. E-mail: \\ comecarpentier@gmail.com
}

\begin{abstract}
CITATION: de Gourdon C.C. (2018) The Rise of the Hindu Religious Factor in Indian Politics and State Theory. Outlines of Global Transformations: Politics, Economics, Law, vol. 11, no 4, pp. 219-232. DOI: 10.23932/2542-0240-2018-11-4-219-232
\end{abstract}

\begin{abstract}
We are living in an age of reaffirmation and revival of religious/national and cultural identities as a reaction to the sweeping onslaught of socio-economic, cultural and technological globalization. In India the demand for a definition of national identity based on Hinduism or on Hindutva (Hinduness) predates the achievement of independence in 1947 and it was gradually reinforced by successive political crises, such as the partition between India and Pakistan, successive wars with Pakistan, the continuing separatist agitation in the Kashmir Valley and the rise of large-scale Islamist terrorism since the $11^{\text {th }}$ of September 2001 if not before. Historically a distinction has been made between Hinduism, as the religion and way of life of more than a billion people in India and in other countries and Hindutva, a cultural ideology and a sociopolitical doctrine which defines a modernized version of Hindu or in broader sense Indic civilisation (encompassing Buddhism, Jainism, Sikhism and other indigenous minority religions). Many Hindus do not accept the premises or least the political theory of Hindutva whereas Hindutva proponents may not be 'believers' in the ritual and theological aspects of Hindu Dharma and may define themselves as sceptics, materialists or atheists. However they conceive of the common Hindu national civilisation and millenary historical heritage as the cement that can bind the country's diverse people togeth-
\end{abstract}

er and they usually reject the 'secular' view that India is the home of a composite culture forged out of many domestic and foreign elements and consisting of diverse ethnic groups which were brought together as a nation by British colonization. This paper succinctly retraces the evolution and expansion of Hindu nationalism in the politics of the country and distinguishes between the various nuances of the ideology which is now the source of inspiration for the National Democratic Alliance led by Prime Minister Narendra Modi. It strives to answer the often asked question: Is India becoming a Hindu State?

KEY WORDS: India, Hinduism, Dharma, Secularism, Hindutva, Nationalism, Indic, Indian Constitution, Syncretism, J. Nehru, B.R. Ambedkar, Hindu Mashasabha, RSS (Rashtriya Swayamsevak Sangh), Bharatiya Janata Party, Muslim League, M A Jinnah

\section{Introduction}

In the decades leading up to independence from British rule the Hindu majoritarian identity of India was accepted as a fact by both the indigenous population and the foreign colonizers. The name Hin$\mathrm{du}$, of alien (Persian) origin, had an ambiguous significance, being rooted in geography (after the river Sindhu/Hindu or 
Indus in Greek). All denizens of Hindustan were since many centuries regarded as 'Hindoos', as opposed to the American 'Indians' and in Latin languages like Spanish or French any inhabitant of India is still commonly called a Hindu.

There was also some controversy about the definition of the hindu religion which encompasses multiple sectarian and cultural identities bound together by geography and history. Yet clear distinctions were kept between Hindus, Muslims and other religious communities of 'foreign origin', as shown by the cleavages between the two major confessions which became a critical factor in the 1857 rebellion against the East India Company and its defeat [Dalrymple 2006; Jain 2010], despite efforts to bridge old divisions and suspicions between Hindus and Muslims.

\section{The Break Up of the Indian Raj}

However paradoxically it was the freedom struggle which, initiated on a common platform, gradually set apart a section of the muslim community from the indian mainstream and eventually led to the partition of the subcontinent. By the 1930s many members of the Muhammedan elite in the subcontinent grew wary of the Hindu dominance of the National Congress and began to plan, through the Muslim League for a state of their own in the event of British departure from the subcontinent. The colonial administrators found this rift very congenial to their interest and demonstrably favoured it [Sarila 2006; Tunzelmann 2007]. Declassified correspondence between British statesmen and colonial administrators and Muslim leaders such as Sir $\mathrm{Mu}-$ hammed Agha Khan and Muhammed Ali Jinnah in India reveals London's support for Muslim separatism and the Two Nation theory propounded by the Muslim League.
In 1939 Jinnah, the godfather of the future Pakistan called the Indian National Congress a 'Hindu Raj' (Hindu Regime) and broke ranks with its decision to oppose the British viceroy's decision to declare India at war with the Axis power without a popular consultation. Muslim separatists systematically sided with the colonial authorities against the Independence movement which they saw as the harbinger of Hindu majority rule.

It has been argued that the religiously nationalistic discourses of some of the great $19^{\text {th }}-20^{\text {th }}$ century Hindu reformers and freedom fighters such as Swami Vivekananda, Sri Aurobindo Ghose, 'Lokamanya' Bal Gangadhar Tilak and the Maratha founders of the RSS and other nationalist "identitarian" outfits, V N Savarkar (18831966) first president of the Hindu Mahasabha, K.B. Hedgewar (1889-1940) and M.S. Golwalkar (1905-1973) who built the Rashtriya Swayamsevak Sangh or RSS ('League of the Nation's Servants') decisively influenced in reaction some Muslim leaders in claiming a separate identity.

Jinnah, though a non-practicing Muslim from a minority sect, inspired by the pan-Islamic discourse of the great poet and philosopher Muhammed Iqbal, opportunistically embraced the theories of the hardliners in the Muslim League who described 'Muhammedans' of the subcontinent as representatives of a different civilization which could not co-exist with a hindu 'heathen' majority.

Iqbal became an outspoken advocate of the Two Nation theory and of Muslim separatism after his return from a four year stay in Europe, in 1908. In 1910 he penned his famous poem Tarana e Milli which became a founding hymn for Pakistan. The beginning is:

Muslim hain ham Chin o Arab hamara Hindustan hamara

Watan hai saara Jahan hamara

(We are Muslims. China, Arabia and India are ours, the whole world is our nation). 
In 1930 in his presidential address the Muslim League in Allahabad he made an eloquent plea for the two-nation theory. In 1937 he wrote to Jinnah calling for "a separate federation of Muslim provinces", arguing that Muslims of India were a nation just as there were other nations in India.

Muslim separatists argued that the Islamic confession and law does not allow its followers to live under the rule of nonMuslims who in a democratic India would inevitably enjoy hegemony and they called for a second Hijra a flight from the lands of the idolaters or unbelievers (kuffara) to a new 'pure' state for the ummah: Pakistan [Dhulipala 2013].

Conversely Golwalkar, one of the RSS founding leaders argued that India ought to be purified of its invading foreign elements so that its pristine hindu identity may be restored. Although in the prevalent language of his time Golwalkar talks of the 'hindu race', he actually means a socio-cultural historic community, in keeping with Savarkar's concept, and not necessarily a genetic stock as such. On the other side of the political spectrum, the outspokenly 'anti-Hindu' B.R. Ambedkar, the main framer of India's national constitution and its first law minister believed that Muslims could not coexist with the majority in independent India and should move to Pakistan, the state being created for them. In that opinion he expressed the old European concept that each state is defined by a majority culture and a main language.

Ambedkar, born in an "outcaste" community, from a father who served in the British Indian army, and educated in the English and American academic systems wrote many highly critical reflections about Hinduism which he regarded as a discriminatory, oppressive, superstitious and unjust religion. He converted to a 'reformed' Buddhism and promoted conversion among the Dalits (outcastes) as a way to rise above their generally miserable condition. In 1940 he wrote: "If Hindu Raj does become a fact, it will, no doubt, be the greatest calamity for the country. No matter what the Hindus say, Hinduism is a menace to the liberty, equality and fraternity. In that regard it is incompatible with democracy. Hindu Raj must be prevented at any cost" [Ambedkar 1940].

For him the common basis for Indian citizenship ought not to be religious Hinduism but a secular form of Indianness, contrary to Iqbal with whom he corresponded at length and who held religion to be the basis of nationality although in Islam he saw a supra-national world-spanning creed.

\section{Champions of Unity}

The separatist point of view was by no means shared by all Indian Muslims and many, following eminent figures like Maulana Abdul Kalam Azad (1888-1958),who became India's first minister for education and Dr Zakir Husain (1887-1969), India's third president held on to an opposite perspective. Like most of their Hindu colleagues in the Congress they saw their future in India ruled by secular law inherited from the British dispensation and confining religion to private life.

To them their democratic freedom and civic equality as Muslims as a formerly dominant minority, with their personal laws and customs preserved, would be ensured by the fact that the State would remain confessionally and legally non-hin$\mathrm{du}$ as it had been during centuries of imperial muslim rule in most of the country's northern and eastern regions and under the British Raj since the early $19^{\text {th }}$ century.

This compromise formula was espoused by the leaders of the Congress, headed by Mahatma Gandhi (despite his strong personal hindu religiosity) and the sceptically minded, rationalist Nehru who shared some of Ambedkar's hostility to socio-political manifestations of the Hindu 
tradition. Although not anti-religious Nehru was suspicious of Hindu revivalism which he saw as a throwback to the feudal, superstitious past. Unsurprisingly Gandhi and Nehru are not highly regarded in the Hindutva ideological family which accuses them of appeasing Muslims and inflicting a step-fatherly treatment to the religion of their birth .

A number of critical assessments of Nehru's personality, ideology and politics have been written in recent years, some by supporters of the BJP and scholars from affiliated organizations [Singh 2015; Puranik 2016]. Gandhi has also come under criticism for his alleged refusal to take sides between Hindus and Muslims during the tragic days of the bloody partition and also for some of his impractical ideas and often eccentric precepts pinpointed in Von Tunzelmann's earlier cited book. The recent republication of Nathuram Godse's memoir [Godse 2015] sums up the thesis of Gandhi's bitterest critics. The present government's tendency is to highlight the roles and revive the memories of other stalwarts of the Independence movement such as Bal Gangadhar Tilak, Vallabhbhai Patel and Subhash Chandra Bose who had fallen into relative obscurity under the long rule of Nehru's descendants and their allies.

One of the points often made by those critical or dismissive of the adoption of secularism as a fundamental principle of the Indian polity is that Muslims wanted and got it both ways. They got their own officially Islamic state while the Hindu majority abstained from granting an equivalent status to their faith and culture partly in recognition of the sensitivity of its largest religious minority. It could be argued that independent India recognized to its remaining muslims 'a state within the state, at least from a legal, cultural and educational standpoint, evidenced by the fact that the Ministry of Religious and Minority Affairs financially sponsored the Haj pilgrimage to Mecca and Medina for poor
Indian Muslims, a practice which the current government has discontinued.

The unofficial but fundamental secularism of the policy was reinforced by Indira Gandhi when, taking advantage of the Emergency Rule she had declared on rather tenuous pretexts, she added to the Constitution's Preamble through the $42^{\text {nd }}$ Amendment [Constitution of India 1978],that India was a secular and socialist republic, two qualifiers which the document's architect Ambedkar had resisted including, probably because he was a US educated jurist who held on to rather economically and socially liberal views, shared by a strong contingent of conservative stalwarts of the Independence movement such as Sardar Vallabhbhai Patel, the first home minister, C Rajagopalachari, India's first non-British governor general, Dr Rajendra Prasad, first president of the Republic, Dr S Radhakrishnan, first vicepresident and Dr Shyama Prasad Mookerji, a former vice-president of the Hindu Mahasabha and the founder of the Jan Sangh, the ancestor of the Bharatiya Janata Party.

Indeed the RSS under Golwalkar's stewardship affirmed its opposition to communism and socialism which it saw as foreign anti-Hindu ideologies and it remains a socially and economically conservative organization. Conversely Muslims in India, although socially conservative, often vote for the purportedly 'left of centre' Congress Party or for left-wing parties which are seen as more favourable to the interests of minorities.

Mrs. Gandhi was influenced in her decision to proclaim state socialism by the then powerful communist parties, close to the USSR, whose support she needed at a time when she was politically isolated. She decided to give those additional sops to religious minorities and leftist politicians in order to retain their backing. Her late father's well known sympathy for the Soviet Union also played a role in her political 
choices. However, by making secularism an explicit tenet of state policy, she unwittingly opened a Pandora's box, notably because there has never been a consensus on the meaning of secularism, a word which is alien to and even meaningless in the Indian cultural context as it applies to almost any attitude to religion, from formal atheism to Nehru's famed 'scientific temper' and can include multi-religious syncretism such as many Hindus instinctively practice or at least invoke but which cannot be imposed either. Indeed translations of secularism in the national languages are necessarily awkward and can only be subjective interpretations.

\section{Hindu Dharma and Secularism}

The sanskrit-hindi word Adharma (devoid of Dharma, the natural sacred law, morality and dutifulness) had to be rejected for obvious reasons as it suggested immorality or cynicism. Dharmaniropeksa (non-discrimination about Dharma which smacks of moral confusion or ethical relativism) was also pejorative and indeed secularism, a concept conceived by the Roman Church originally means 'living in the century' like a priest (not in a monastery but amidst society), or as a lay person i.e. not a member of a religious order. $\mathrm{Ob}$ viously secular people were still supposed to be Catholics since that was the state religion. However spiritual and moral writings in medieval Europe often took a dim view of the 'secular man" whom they described as superficial and concerned only with the outer reality of the world and the mundane benefits of social life. Thus according to Oscar Wilde's witticism, a secular person is one who has 'no invisible means of support', not a very auspicious way to define an individual attitude or a human community.

All Hindus who are not ascetics or members of a religious order may be re- garded as secular by one definition but that does not preclude them being devout practitioners of their faith according to one definition although, according to another they should have a skeptical outlook or at least keep their faith private.

Arvind Sharma [Sharma 2018] is one of the scholars who has pointed out that 'religion' is an inaccurate and misleading translation for the word Dharma and that the common interpretation of secularism in Sanskrit and most Northern Indian languages as sarva-dharma-samabha$v a$ : same attitude to all dharmas or a belief that all dharmas are the same also creates misgivings, firstly because followers of most religions would not agree to equate all religions as being similar or identical and secondly because it puts Hindus as a disadvantage since they are expected to agree that all other creeds are equivalent to theirs, even when some of those faiths (such as Christianity and Islam) deny the validity of Hinduism and urge conversion from 'idolatry' or paganism. That concept of secularism may be understood either as a mystical pantheistic or syncretistic realization or as a politically convenient compromise which does not rest on a commonly shared conviction.

If Hinduism or Dharma in its many forms and nuances is seen as a culture or as a fundamental component of Indian civilization for several thousand years, it is illogical to proscribe it in matters of public policy, education and law, just as it would be absurd to ban expressions of the national culture in the socio-political and legal system of any country. Insofar as Dharma or 'hinduness' does not specify an obligatory form of worship, political ideology and educational model but only lays out broad, adaptable principles, it is not antithetical either to a democratic system of government or to changes required by the passage of time and evolution of mankind.

History shows that Hindu kingdoms which survived under british paramount- 
cy in the subcontinent until Independence were open and hospitable to all creeds and sects and gave them freedom to build sanctuaries and educational facilities, celebrate their festivals and propagate their beliefs, even absolutist exclusive ones.

The traditional vedic reverence for spiritual teachers and holders of knowledge in all fields especially in the scientific and mystical domains remains alive among the Indians and many Muslim rulers in the subcontinent adopted that tolerant attitude as well. Such was the Mughal Emperor Akbar, perhaps the most 'Hindu' in his dynasty, who visited saintly men of all faiths (as most of his successors did) and hosted debates between representatives of major religions in his palace, listening with impartiality and honoring them all according to the principle of Suhl e Kul, An Arabic term of Sufi inspiration which means 'universal peace" and expresses an ideal of inter-religious concord.

Supporters of an offiicially Hindu India or Bharat (her ancient native name) usually point out that, contrary to missionary, prophetic religions which command obedience to a formal hierarchy and belief in edicted precepts, usually contained in a holy book, the Hindu or Indic civilization accepts many scriptures as sacred but places a higher emphasis on the living word and on actual human (or super-human) spiritual teachers, putting the accent on the quest for personal spiritual happiness, liberation or bliss through mental, devotional, physical or social practices.

'Veer' Savarkar called Hindus 'people who live as children of a common motherland, adoring a common holyland' [Savarkar 1928] and he fought for the nation's territorial integrity (Akhand Bharat), fiercely resisting partition. Indeed in the years before Pakistan's secession, his Hindu Mahasabha formed coalition governments with Islamic parties in Muslim majority provinces which were soon to become parts of West and East Pakistan, in an attempt to keep India together, showing that it put national unity above religious differences.

The Vedas and related texts are the touchstones of Hinduness, at least conventionally, but most Hindus, even though accepting the divine character of the Vedas, follow personal teachers, living or dead, traditional or reformist, and are more familiar with vernacular popular texts and forms of worship than with the often obscure mythological, ritual and symbolic hymns of the plurimillennial Sruti (received or heard vedic gnosis) which does not call for a single interpretation and a uniform set of rules applicable to all.

Buddhists, Jains and Sikhs abide by other indic creeds which do not regard the Vedas as authoritative and yet are indisputably branches of the Bharatiya Dharma as all hindu nationalist movements affirm.

Indira Gandhi who did not share her father's agnosticism often evinced, like many Indians her respect for and even her acceptance of the basic tenets of all great faiths: Hinduism, Buddhism, Islam, Jainism, Sikhism, Christianity and Zoroastrianism. She wanted India to be legally multi-religious but not irreligious and remained personally a Hindu.

\section{The Identitarian Impulse}

However, as we point out at the outset of this paper, worldwide there is a growing trend to return to one's roots, to reassert national and regional cultural identities and traditions, howbeit in a modernized form. We can notice that trend at work in countries as diverse as Turkey, Poland, the United Kingdom, China, the United States and Russia.

Universalistic and 'globalist' ideologies are not necessarily rejected but they don't appeal to the less privileged majorities which see them as abstract, theoretical and not suitable to their needs and desires 
to retain distinct features and prerogatives. In India, in reaction to what has happened in Pakistan and in the wider Islamic region but also to a lesser degree in Sri Lanka and in other predominantly Buddhist nations there is a widespread yearning for more indigenous forms of education and administration which sometimes combine and yet conflict with the westernizing tropism of reformers and modernizers still following Nehru and Ambedkar, heavily inspired by the colonial notions and structures left by the British Raj and indoctrinated in foreign schools of thought, whether liberal, marxist or social-democratic.

Significantly the global hindu diaspora, particularly from the prosperous communities settled in North America and other Anglo-Saxon regions, plays an active role in the religious-nationalistic reassertion. Like many "exiles", voluntary or deported migrants at various periods of history, the Hindus overseas feel the nostalgia of the mother country as they remember or imagine it and cultivate revivalist ideals which they frequently support financially and by their activism.

Rajiv Malhotra is an American Indian widely known in his native land for his books and his polemics against Indian leftists and secularists and against indological scholars who take a jaundiced view, often influenced by Freudian psycho-analytical or Marxist interpretations of Hindu tenets and practices but there are several less famous persons of Indian origin who campaign in various ways against Nehruvian secularism and Marxist versions of history and culture and in support of the current BJP-led Government.

Among influential foreign scholars who defend the hindu nationalist programme the American sanskritist and historian David Frawley (Vamadeva Shastri), a prolific author and practicing Hindu and the Belgian agnostic Indologist Koenraad Elst, who defines himself as a secular humanist, are perhaps the most eminent. Elst has written extensively on the well known controversy about the destruction of the Babri mosque on the holy hindu site of Ayodhya in 1992.

It is important to keep in mind that there are at least two major intellectual factions within the domestic Hindutva family. The first is made up of 'traditional' spiritualists, attached to their religious and/ or metaphysical heritage in all its facets. They highlight its diversity, tolerance and lack of dogmatism and reject the materialistic objectivism implanted through western influence in the contemporary Indian educational system. Many of them actually don't quite accept the standard Hindutva definition which they find too 'collectivist' and restricted in contrast to the immensely varied and constantly evolving paradigm of Sanathana Dharma (the eternal law) which takes a different aspect to every individual Hindu.

Members of the second faction can be defined as cultural materialists, often inspired by the writings of Savarkar who described himself as an atheist, a pragmatist and a positivist. In their desire to modernize and upgrade society they borrow the western rationalist and Cartesian approach but, also like Savarkar, they see religion as a nation-building, unifying factor once it is normalized as a state creed as in countries where it is a pillar of the state.

Those Hindu rationalists have little time for beliefs, rituals and spiritual teachings which they regards as superstitious, impractical and quaint but they hold on to Hinduism as the principle of the civilizational identity of the people although they tend to heed Nehru's call for 'scientific temper' to redefine Hinduism instead of adopting a westernized agnostic cosmopolitan approach as Nehru did. Like Savarkar they reject caste-based and ethnic distinctions, including the practices rooted in the concept of untouchability.

Unsurprisingly those 'rationalist' hindutvadis take a dim view of other, foreign- 
born denominations because of their potentially fissiparous and divisive influence on the body politic and they actually prefer atheists to the faithful of non-hindu creeds. They would probably subscribe to Napoleon's reported quip that "if religion did not exist, it would be necessary to invent it", and like him they wish it to serve political objectives. They may be regarded as intellectual heirs of the ancient and medieval lokayata, carvaka or brhaspatya 'pragmatic' and materialistic philosophical systems which were fiercely opposed by both the Buddhist and spiritualist Hindu logicians and metaphysicians in their days.

However materialist doctrines inspired the science of statecraft (nitisastra) expounded in Chanakya's Arthasastra and in other political treatises which take a cynical view of human nature and behaviour and separate public policy from religious concerns.

This ideological division does not prevent the votaries and militants of 'hinduness' and many simple 'pious Hindus' from working together towards the goal of reaffirming what they describe as the essence of the nation's identity in its polity and institutions. They often jointly argue or at least disagree with more "quietist" or mystical co-religionaries who regard their beliefs and customs as personal matters that need not be reflected explicitly in matters of state policy and social ideology. One of the major concerns of the latter is not to upset the delicate balance that has usually maintained social peace between the various communities and still prevents major long term conflicts, with Muslims and Christians in particular.

In response the supporters of Hindutva make the case that a conscious and affirmed awareness of the common ancestral identity, transcending personal or communal creeds can only strengthen the country and protect its unity by preventing new splits after the tragic secession of Pakistan which still fuels the fires of anti-
Indian rebellion in Kashmir. They point to the threats raised by leftist tribal and 'outcaste' rebellions in other regions which are often supported by subversive foreign political or religious forces.

Therefore, in spite of their allegedly divisive doctrine, they call for organic unity of all patriotic Bharatiyas (Indians) whereas formal secularists, following the prevailing theories of western Indologists, are wont to put the emphasis on the many communities, castes, creeds and ethnic origins of Indians to support the conclusion that, as Strachey famously declared, India was never a nation before the British forged it into one -or rather into two when they left ("There is not and never was an India possessing... any sort of unity, physical, political, social or religious, no Indian Nation" [Strachey 1888]).

\section{Is Hindutva a theocratic doctrine?}

Hinduness is held by Hindutva proponents to be different from the confessional exclusiveness claimed by the upholders of Islamic, Christian or even Buddhist states -or by the religious Jewish citizens of Israel - who may tolerate the followers of other faiths without accepting the validity of their doctrines, wrong or incomplete from the standpoint of prophetic revealed creeds.

Buddhists are not believers in a particular concept of God taught by a prophet or divine figure but they are still required to 'take refuge in the Buddha, the Dharma and the Sangha' whereas Hindus or adepts of the Sanathana Dharma as they define themselves, are mainly connected by a common geo-historical ethos which encompasses many diverse linguistic and ethnic communities, beliefs (including atheism), practices and traditions.

In that sense Hindutva or Hinduness would be closer to "Britishness" or "Latinity", or even to Jewishness (which is cul- 
turally plural and not necessarily religious or even ethnic) than to a theistic denomination. That is how many Hindus point out that 'real secularism' or, more precisely genuine religious freedom, respect and acceptance is enshrined in their heritage and goes much deeper than the essentially sceptical or agnostic 'laicite' (in practice atheistic) practiced by the French Republic because it does not say that all religions are the same in their truth or lack of it but rather professes that they are connected by their common transcendent source. The difference is that whereas laicité is rooted in a materialistic vision of the world which a priori does not accept any claim to a higher realm of being or is indifferent to it, Sanathana Dharma is fundamentally spiritual. It is not indifferent but accepts and even honours differences. It says that truth is one (Ekam Sat) and always prevails (Satyameva Jayate) but not that it belongs to one religion alone. Instead it points out that sages speak of it in many ways (vipra bahudha vadanti) as is repeated in many sacred and canonical texts.

\section{The Current Debate}

Since the BJP led Government came back to power in 2014, the long-standing controversies between supporters and opponents of the Hindutva ideology have predictably intensified now that the ruling power has absolute majority in the lower member of Parliament and governs a majority of the States of the Union. The President of India Ramnath Kovind is a former BJP cadre. Prime Minister Narendra Modi and several members of his cabinet as well as most top members of the BJP belong to the RSS in which they were trained for public life. Although Modi has shown a pragmatic disposition and focuses on growing the economy and modernizing the state apparatus there is no doubt that his personal convictions are in tune with the RSS philosophy. His government is ostensibly committed to reforming and transforming the country on the lines set by Hindutva thinkers drawing inspiration from the ancient native civilization of the land.

The well known historian Romila Thapar in a book edited by Ramin Jahanbegloo and Niladri Bhattacharya and titled Talking History [Jahanbegloo, Bhattacharya 2017] has argued that equating Hindutva to Hinduism is problematic as Hindutva according to her homogenizes Hinduism around a uniform set of beliefs and therefore sets Hindus apart from other Indians who don't accept it.

While conceding that Hindutva does not attempt to redefine Hinduism as a religion per se she claims that "it redefines the social controls exercised by the religion. Hindutva is trying to make Hinduism uniform by incorporating all the sects so that it becomes a monolithic religion" which she dubs as 'syndicated Hinduism'. She notes that 'the emphasis is on social organization and political mobilization' (Scroll.in, 4 February 2018).

An eminent intellectual and Congress politician, Shashi Tharoor in a interview [Tharoor 2018] has accused the government of Narendra Modi of planning a "major attack' on the Constitution by stripping it of references to secularism and socialism and affirming the Hindu character of the nation, declaring it a Hindu Rashtra. He calls that 'religiously derived majoritarianism' and recalls that one of the intellectual father-figures of the nationalist Hindu camp, Deen Dayal Upadhyaya wanted the Constitution to be 'shredded' because it was built around alien, western ideas of state and society. Tharoor adds that a Committee has been formed by the Modi government under the chairmanship of Dr Govindacharya in order to study possible amendments to it.

Tharoor opposes his own and Congress's 'private' practice of religion to the 
BJP's sponsorship of Hinduism as a political axis for the nation but he acknowledges that his own party, beginning with Congress President Rahul Gandhi is now also emphasizing the Hindu allegiance of most of its members by staging highly publicized visits to, and ritual worship in temples. He thereby concedes the changing public mood which gives greater importance to the country's fundamental religious legacy.

Although there is no consensus among supporters of the current government on the exact extent of the reform desired, it is to be expected that the latter will reflect, if it is carried out, the views of the RSS which promotes a nationalist, activist, egalitarian and collective kind of Dharma, favourable to free enterprise but suspicious of globalization and sceptical about Mahatma Gandhi's pacifist and arguably utopian doctrine which at a certain level has permeated the country's polity since before Independence, at least in theory.

An important step in the process of changing India's self perception and its image in the outside world is the Ministry of Education's initiative to appoint an interdisciplinary scientific committee for revising and rewriting the educational manuals on history [A Committee Chosen by Modi Government To Rewrite India's 2018].

The official purpose of this body headed by senior Archaeologist KN Dikshit is the "holistic study of the origin and evolution of Indian culture since 12000 before present and its interface with other cultures of the world". The task is to build a new narrative to balance the liberal and secular philosophy expressed by Nehru and his successors. One of the concerns of the present dispensation is to affirm the mostly indigenous nature of indic civilisation, its continuity since the period of the Indus-Saraswati archaeological sites while dismissing the reality or at least the cultural importance of the longalleged 'Aryan Invasion' promoted by European scholars in the $19^{\text {th }}$ century on the ba- sis of flimsy or erroneous data and without any solid proof.

Despite its pan-Indian and somewhat supra-religious definition, the project to formally define the country as a Hindu State is being opposed and will continued to be resisted by many, on the left of the political spectrum but also among nominal and 'moderate' Hindus as within the religious and political minorities, especially Muslims and Christians, who usually resent, or at least are suspicious of, any formulation which seeks to bracket them within the majority but may leave them feeling that they are 'dissenters' from the common national creed, which is how the RSS ideologues tend to describe them. Indeed a campaign for ghar wapsi (home return) or reconversion to Hinduism is being carried out in various parts of the country by religious organizations affiliated or sympathetic to the RSS but they mostly address recent converts to protestant or evangelical christianity, usually among disadvantaged or tribal communities although there are some cases of Indian Muslims rejoining the hindu faith.

Both Christianity and Islam gather and inspire supra-national faith communities which have their respective centres in Rome, Jerusalem and Mecca and many in those populations, especially in the missionary churches and fundamentalist muslim sects would not like to be regarded as members of an officially hindu national polity. The issue is thus a thorny one even if most Indian Christians and Muslims are indigenous and take pride in the specifically Indian and syncretistic features of their practices, called Ganga-Yamuna Tehzeeb in the Sufi Islamic Indian context.

Dogmatists on all sides sometimes make pregnant and even ominous distinctions between those who see themselves as Muslim Indians and those who would rather be treated as Muslims in India (the latter being the term adopted by the Muslim League and the founders of Pakistan). 


\section{Conclusion}

Given the real prospect that, if reelected to power in 2019, the current Indian Government could amend the Constitution to declare the country a Hindu State or Republic and no longer a secular, socialist one, it is necessary to consider the possible consequences of such a reform both at home and abroad, even if little changes in reality and in practice.

A formally Hindu India would constitute a long delayed response to Pakistan's self-proclamation as a Muslim nation and would join smaller neighbours such as Sri Lanka, Myanmar and Thailand, officially Buddhist States in affirming a foundational civilisational identity. Further afield, Japan's Imperial head embodies the nation's Buddhist-Shinto identity whereas Russia is a Christian orthodox country.

In the West the british monarch remains the head of the national church and "protector of the faith" as is the case nominally for the other Kings of Europe. Germany and the USA among many others define themselves as Christian countries although, like the monarchies mentioned above they guarantee freedom of conscience and worship and enshrine in their constitutions the separation of religion from the exercise of governance. Yet it must be observed that until recently the relative tolerance of Christian and of some Muslim states in matters of religions extended only to monotheistic (abrahamic) faiths and to atheism (still frowned upon in the USA) and had no formal space for 'paganism. Hindu India obviously never enforced such discrimination as the notion of paganism is alien to the Indic religious universe, even if certain schools of thought (such as lokayata) fell into disrepute and are still rejected by the majority of the population.

The various communities were entitled to their own religious traditions and practices even though the Brahminical castes held a hierarchical superiority in the social order but had to negotiate their role with other communities, mainly the royal and aristocratic ksatriya families and the merchant (vaisya or bania) clans from which they usually drew their livelihood.

If handled well and appropriately defined, the assumption of its Hindu heritage as the foundation of its civilization should not be seen as a challenge to Bharat-India's organic unity and social stability.

As various voices, even within the minorities communities have noted, the essential quality of India's native, universalistic secularism (vasudhaiva kutumbakam: 'the world is a family'), its openness and lack of dogmatism, its respect for all spiritual traditions and teachings and its generally non-violent attitude to differences and contradictions lies precisely in the Sanathana Dharma which the Hindutva doctrine must faithfully preserve without taking cues from the more rigid and hierarchical religions (whether monotheistic or atheistic) that see it as their enemy because of its resistance to their projects for conversion and expansion.

\section{References}

A Committee Chosen by Modi Government To Rewrite India's History (2018). NDTV Newsdesk (with inputs from Reuters), March 6, 2018. Available at: https://www.ndtv.com/india-news/a-committee-chosen-by-modi-government-torewrite-indias-history-report-1820397, accessed 20.07.2018.

Ambedkar B.R. (1940) Pakistan or The Partition of India, Bombay: Thackers.

Constitution of India, $42^{\text {nd }}$ Amendment (1978), Preamble.

Dalrymple W. (2006) The Last Mughal, The Fall of a Dynasty. Delhi 1857, New Delhi: Bloomsbury.

Dhulipala V. (2013) Towards a New Medina: Jinnah, the Deobandi Ulema and 
the Quest for Pakistan in late Colonial India, New Delhi.

Elst K. (2000) Decolonizing the Hindu Mind - Ideological Development of Hindu Revivalism, New Delhi: Rupa.

Elst K. (2001) The Saffron Swastika The Notion of Hindu Fascism, New Delhi: Rupa.

Frawley D. (1998) Awaken Bharata, A Call for India's Rebirth, New Delhi: Aditya Prakashan.

Frawley D. (2010) Universal Hinduism: Towards a New View of Sanathana Dharma, New Delhi: Voice of India.

Godse N. (2015) Why I Assassinated Mahatma Gandhi, New Delhi: Hindi Sahitya Sadan.

Golwalkar M.S. (1966) Bunch of Thought, New Delhi: Sahitya Sindhu Prakashana.

Jahanbegloo R., Bhattacharya N. (2017) Romila Thapar, Talking History, New Delhi: OUP.

Jain M. (2010) Parallel Pathways - Essays on Hindu-Muslim Relations, 17071857, New Delhi: Konark.

Malhotra R. (2011) Being Different, An Indian Challenge to Western Universalism, New Delhi: Harper Collins.

Malhotra R. (2016) Indra's Net, Defending Hinduism's Philosophical Unity, New Delhi: Harper Collims.
Puranik R. (2016) Nehru's 97 Major Blunders, New Delhi: Pustak Mahal.

Ramaswamy K., Banerjee A. (2007) Invading The Sacred -An Analysis of Hinduism Studies in America, New Delhi: Rupa.

Rajan R. (2009) Eclipse of the Hindu Nation - Gandhi and his Freedom Struggle, Kolkata: New Age Publishers.

Sarila N.S. (2006) Shadow of the Great Game - The Untold Story of India's Partition, London: Constable.

Savarkar V.D. (1928) Who is a Hindu? New Delhi: Veer Savarkar Prakashan.

Sharma A. (2018) Western Concepts and Indian Realities, New Delhi (IIC Additional Publication 84).

Singh R.N.P. (2016) Nehru: A Troubled Legacy, New Delhi: Wisdom Tree.

Strachey J. (1888) India, Its Administration and Progress, London: MacMillan.

Tharoor S. (2018) BJP Planning 'Major Assault' on the Constitution. NDTV Newsdesk, February 8, 2018. Available at: https://www.ndtv.com/india-news/bjpplanning-major-assault-on-constitution-shashi-tharoor-1810236, accessed 20.07.2018.

Tunzelmann A. von (2007) Indian Summer - The Secret Story of the End of an Empire, New York: Henry Holt and Company. 


\section{Усиление влияния религиозной традиции индуизма в индийской политике и политической теории}

\section{Ком Карпентье де ГУРДОН}

координатор международного совета по вопросам мировой политики - Журнал международных проблем (Индия). Адрес: D-322, Defence Colony, New Delhi, 110 024, India. E-mail: comecarpentier@gmail.com

\section{ЦИТИРОВАНИЕ: de Gourdon С.С. (2018) The Rise of the Hindu Religious Factor in Indian Politics and State Theory. Outlines of Global Transformations: Politics, Economics, Law, vol. 11, no 4, pp. 219-232. DOI: 10.23932/2542-0240-2018-11-4-219-232}

АННОТАЦИЯ. Мы живем в век переосмысления и возрождения религиозной, национальной и культурной идентичности как реакиии на стремительный натиск сочиально-экономической, культурной и технологчческой глобализаизи. В Индии стремление к национальной идентичности, основанное на индуизме или на индусскости, предшествовало обретению независимости в 1947 году. Это стремление постепенно укреплялось в силу постоянных политических кризисов, среди которых можно отметить разделение на Индию и Пакистан, войнь между ними, непрекрашаюшуюся сепаратистскую агитаиию в долине Кашмира и рост широкомасштабного исламистского терроризма с 11 сентября 2001 года. Исторически принято проводить различие между индуизмом как религией и образом жизни более миллиарда человек в Индии и других странах - и индуистской культу рой, культурной идеологией и сочиально-политической доктриной, которая определяет модернизированную версию индуистской или, шире, индийской иивилизации (включая буддизм, джайнизм, сикхизм и другие религии коренньх народов). Многие индусы не согласны с идеями или политической теорией индусскости, тогда как сторонники последней могут не быть верующими в ритуальных и богословских аспектах индуистской Дхармы и могут определять себя как скептики, материалисты или атеисты. Однако они воспринимают общую индуистскую национальную ицвилизацию, рассматривая тысячелетнее историческое наследие как иемент, который может связывать разнообразные группы людей, живущих в стране. Кроме того, они обычно отвергают «светское» мнение о том, что Индия - место общей культуры, скрепляющее воедино многие внутренние и внешние элементы и состоящее из разнообразных этнических групп, которые были объединены как нация британской колонизацией. Эта статья содержит общий обзор эволюциии и расширения индуистского национализма в политике страны и показывает разнообразные нюансы идеологии, которая сейчас является источником вдохновения для Национального демократического альянса во главе с премьерминистром Нарендрой Моди. Предлагаемая статья - попытка ответить на часто задаваемый вопрос: превращается ли Индия в индуистское государство?

КЛЮЧЕВЫЕ СЛОВА: Индия, индуนЗМ, дхарма, секуляризм, индусскость, начионализм, индийский, индийская консти- 
туичия, синкретизм, Дж. Неру, Б.Р. Амбедкар, Хинду Махасабха, Раштри́я сваямсе́вак сангх (Союз добровольных слуг Родины), партия Бхаратия Джаната, Мусульманская лига, М.А. Джинна

\section{Список литературы}

A Committee Chosen by Modi Government To Rewrite India's History (2018) // NDTV Newsdesk (with inputs from Reuters), March 6, 2018 // https://www.ndtv. com/india-news/a-committee-chosen-bymodi-government-to-rewrite-indias-history-report-1820397, дата обращения 20.07.2018.

Ambedkar B.R. (1940) Pakistan or The Partition of India, Bombay: Thackers.

Constitution of India, 42 ${ }^{\text {nd }}$ Amendment (1978), Preamble.

Dalrymple W. (2006) The Last Mughal, The Fall of a Dynasty. Delhi 1857, New Delhi: Bloomsbury.

Dhulipala V. (2013) Towards a New Medina: Jinnah, the Deobandi Ulema and the Quest for Pakistan in late Colonial India, New Delhi.

Elst K. (2000) Decolonizing the Hindu Mind - Ideological Development of Hindu Revivalism, New Delhi: Rupa.

Elst K. (2001) The Saffron Swastika The Notion of Hindu Fascism, New Delhi: Rupa.

Frawley D. (1998) Awaken Bharata, A Call for India's Rebirth, New Delhi: Aditya Prakashan.

Frawley D. (2010) Universal Hinduism: Towards a New View of Sanathana Dharma, New Delhi: Voice of India.

Godse N. (2015) Why I Assassinated Mahatma Gandhi, New Delhi: Hindi Sahitya Sadan.

Golwalkar M.S. (1966) Bunch of Thought, New Delhi: Sahitya Sindhu Prakashana.
Jahanbegloo R., Bhattacharya N. (2017) Romila Thapar, Talking History, New Delhi: OUP.

Jain M. (2010) Parallel Pathways - Essays on Hindu-Muslim Relations, 17071857, New Delhi: Konark.

Malhotra R. (2011) Being Different, An Indian Challenge to Western Universalism, New Delhi: Harper Collins.

Malhotra R. (2016) Indra's Net, Defending Hinduism's Philosophical Unity, New Delhi: Harper Collims.

Puranik R. (2016) Nehru's 97 Major Blunders, New Delhi: Pustak Mahal.

Ramaswamy K., Banerjee A. (2007) Invading The Sacred -An Analysis of Hinduism Studies in America, New Delhi: Rupa.

Rajan R. (2009) Eclipse of the Hindu Nation - Gandhi and his Freedom Struggle, Kolkata: New Age Publishers.

Sarila N.S. (2006) Shadow of the Great Game - The Untold Story of India's Partition, London: Constable.

Savarkar V.D. (1928) Who is a Hindu? New Delhi: Veer Savarkar Prakashan.

Sharma A. (2018) Western Concepts and Indian Realities, New Delhi (IIC Additional Publication 84).

Singh R.N.P. (2016) Nehru: A Troubled Legacy, New Delhi: Wisdom Tree.

Strachey J. (1888) India, Its Administration and Progress, London: MacMillan.

Tharoor S. (2018) BJP Planning 'Major Assault' on the Constitution // NDTV Newsdesk, February 8, 2018 // https://www.ndtv.com/india-news/bjpplanning-major-assault-on-constitutionshashi-tharoor-1810236, дата обращения 20.07.2018.

Tunzelmann A. von (2007) Indian Summer - The Secret Story of the End of an Empire, New York: Henry Holt and Company. 